\title{
PRODUCTION POTENTIAL OF FIRST CALVING SIMMENTAL HEIFERS IN SERBIA
}

\author{
D. Nikšić ${ }^{1}$ D. Ostojić-Andrić ${ }^{1}$, V. Pantelić ${ }^{1}$, P. Perišić ${ }^{2}$, Ž. Novaković $^{1}$, \\ S. Aleksić ${ }^{1}$, M. Lazarević ${ }^{1}$ \\ ${ }^{1}$ Institute for Animal Husbandry, Autoput 16, P. Box 23, 11080, Belgrade-Zemun, Republic of Serbia \\ ${ }^{2}$ Faculty of Agriculture, Nemanjina 6, 11080, Belgrade-Zemun, Republic of Serbia \\ Corresponding author: draganniksic84@gmail.com \\ Original scientific paper
}

\begin{abstract}
Cattle production in Serbia, and especially milk production, contributes significantly to the value of total agricultural production $(20 \%)$ and livestock production (45\%). Achieved annual rate of milk yield increase of approx.100 kg per cow cannot adequately compensate for drastic decrease of number of dairy cattle which dropped by fifth over last decade. This is especially important from the aspect of assessment of future production quotas for milk as part of Serbia's preparation for EU accession. From the aspect of the genetic potential of dairy cattle, the most significant measure aimed at increase of milk performance in future will be execution of systematic selection-breeding work in the main population. Special attention should be directed in future to selection of parents of dairy herd, criteria for selection of heifers and their adequate rearing in sense of nutrition and housing. For the purpose of establishing of production potential of first calving Simmental cows in Serbia, data was analyzed for 37.171 Simmental cows with completed lactations in the period 2007 to 2010. Research results showed moderate trend of increase in milk performance in first calving cows - average milk production of $4.348 \mathrm{~kg}$, milk fat content of $3.93 \%$ and milk fat yield of $171.1 \mathrm{~kg}$. Milk performance of first calving cows in average was lower by $147 \mathrm{~kg}$ compared to cows in other lactations and by $1.169 \mathrm{~kg}$ compared to bull dams in the observed period. In analysis of bulls - most common sires of studied first-calvers, it was established that eight of ten bull sires had negative values for milk yield, which indicated the need for better cooperation and organization in work of all services which are included in selection-breeding activities in dairy cattle breeding.
\end{abstract}

Key words: Simmental breed, first calving cows, milk, milk fat 


\section{Introduction}

Simmental cattle breed is one of the oldest breeds in Europe, and with population of around 41 million heads it is the second largest breeding in the world. It is developed to provide maximum productivity in production of milk with high share of fat and proteins, on nutrition based mainly on roughage. In Serbia, Simmental breed has significant contribution in milk production (78\%) considering that in total cattle breed structure it participates with $80 \%$, total of 819.000 animals, of which 538.000 are cows and pregnant heifers. Also, in recent years, number of dairy cattle in Serbia dropped significantly, but number of animals in population under control remained the same, however, the size of population under control is still low and not enough for successful selection-breeding work. Compared to Simmental population in Bavaria $(C R V, 2010)$, where share of animals under control is $52 \%$ and share of cows under milk recording program $76 \%$, in Serbia these indicators are $13,3 \%$ and $6,5 \%$ respectively (GOO, 2010).

Milk performance of cows under control in domestic population is continuously improving, but it is still significantly lower in comparison with Bavarian population. So, in 2010, average milk performance in Serbia was 4.553 $\mathrm{kg}$ of milk with 3,94\% of milk fat, and in Bavarian population it was $7.096 \mathrm{~kg}$ of milk with $4,13 \%$ of milk fat. Also, results of comparative study of domestic and Austrian Simmental first calvers in same rearing conditions (Medić et al., 2006) showed that in all imported animals higher milk production was recorded by significant $1.171 \mathrm{~kg}$ and $0,49 \%$ of milk fat. In research by Strapak and Strapakova (1997) higher milk yield $(+626 \mathrm{~kg})$ and higher milk fat content $(+0.57 \%)$ were established in imported Simmental cattle compared to domestic Slovak Simmental population.

In the study of the genetic correlation between milk performance traits and fertility of first calving cows of Simmental breed, Pantelić et al.(2008) concluded that the average duration of lactation was 311,72 days, milk yield $3.885,96 \mathrm{~kg}$, milk fat content $3.88 \%$, milk fat yield $150.63 \mathrm{~kg}$ and yield of $4 \% \mathrm{FCM} 3.813,84 \mathrm{~kg}$.

In addition to yield, quality of milk, in Serbia, also is problem since according to statement by Rajic et al. (2007), only 5\% of milk is of extra quality and around $30 \%$ of I class, which clearly indicates the need for improvement of milk quality in sense of its chemical composition and somatic cell count. It is apparent that in spite of significant efforts by selection specialists and breeders (selection in pure breed or meliorative crossing of Simmental breed with Red Holstein-Friesian breed) invested in increase of milk performance, the genetic potential of Simmental dairy cattle have still not been fully used.

One of the major pre-conditions for ensuring long term high-yielding dairy population is systematic work focused on genetic improvement and rearing of breeding progeny. Selection of high quality heifers and first calvers to represent the 
next generations of dairy herds, their proper rearing in regard to nutrition, housing and health care, is of major importance for realization of set breeding goals in cattle production. Production results of first calving cows are first direct indicators of the genetic and production value, and according to Haworth et al. (2008) they are reliable indicator of milk yield in subsequent lactations.

In this paper, production results of Simmental first calving cows over three year period, from 2007 to 2010 are presented, with aim to present to the scientific public the genetic potential of our population in respect to productivity of Simmental breed, and also to point out to some deficiencies and recommend and suggest adequate solutions for future selection-breeding work.

\section{Materials and Methods}

In the study of the production potential of Simmental first calvers data from the main register/records on concluded lactations of 37.171 animals which calved in the period from 2007 to 2010. Most of first calving cows were reared on family holdings/farms, and less come from commercial farms located in Central Serbia. Milk recording was done using the reference $\mathrm{A}_{4}$ method and calculation of lactation using Test interval method (ICAR, 2009). Study included milk performance parameters (milk yield in $\mathrm{kg}$; content of milk fat in \%; milk fat yield in $\mathrm{kg}$ ) in standard first lactation (305 days). A sub-sample of data from 11.372 first calving cows which were included in progeny testing of bulls for milk performance was extracted from the total sample in order to determine the frequency of exploitation of bulls and evaluate the success of their use on production performance of the population.

Data was processed using statistical program StatSoft.Inc (2004), Statistica for Windows version 7 to determine mean, minimum and maximum values, as well as variability measures (standard deviation-SD and variation coefficient $-\mathrm{CV}$ ).

\section{Results and Discussion}

In Table 1 and Graph 1 production results of first calving Simmental cows during the period 2007 to 2010 are presented. Number of first calving cows under milk recording - lactation control increased in 2010, when total of 8.200 were under control, however an increase of milk yield of 5\% compared to 2009 when the milk yield was the lowest, was registered. By comparing the results obtained in similar researches Miščević et al. (1995), Perišić et al. (1999b) and Petrović et al (1999, 2006) with results presented in this study, it is obvious that milk performance of first calving Simmental cows in Serbia has positive trend reflected in over 4 thousand litres of milk annually in standard lactation. However, according to data of ICAR (2011,) populations of Simmental first calvers in developed 
countries (Germany, Austria, Czech Republic, etc.) realize considerably higher milk performance (5000-6000 kg). Compared to situation in Croatia (HPA, 2010), as neighbouring country, in 2010, share of first calvers under control in Serbia was three times lower and quantities of milk and milk fat produced were in average lower by $399 \mathrm{~kg}$ and $18 \mathrm{~kg}$, respectively.

Table 1. Number and average milk production of first-calving Simmental cows (2007-2010)

\begin{tabular}{|c|c|c|c|c|c|c|c|c|c|c|c|c|c|c|c|c|}
\hline \multirow{3}{*}{ Year } & \multirow{3}{*}{$\mathrm{N}$} & \multicolumn{15}{|c|}{ Milk production in standard lactation (305 days) } \\
\hline & & \multicolumn{5}{|c|}{ Milk,kg } & \multicolumn{5}{|c|}{ Milk fat, $\%$} & \multicolumn{5}{|c|}{ Milk fat, $\mathrm{kg}$} \\
\hline & & $\begin{array}{c}\text { Aver } \\
\text {. }\end{array}$ & Min & Max & SD. & \begin{tabular}{|c|} 
Index \\
$(2009=$ \\
$100 \%)$
\end{tabular} & Aver. & Min & Max & SD. & $\mathrm{CV}$ & Aver. & Min & Max & SD. & $\mathrm{CV}$ \\
\hline 2007 & 8618 & 4301 & 1847 & 7637 & 628.5 & 102 & 3.9 & 3.3 & 4.6 & 0.1 & 2.7 & 168.4 & 64.0 & 312.2 & 25.2 & 15.0 \\
\hline 2008 & 9934 & 4392 & 2663 & 7745 & 629.6 & 104 & 3.9 & 3.3 & 4.4 & 0.1 & 2.1 & 172.6 & 103.3 & 316.0 & 26.3 & 15.2 \\
\hline 2009 & 10418 & 4238 & 1675 & 8303 & 585.5 & 100 & 3.9 & 3.3 & 4.7 & 0.1 & 2.8 & 167.1 & 65.9 & 320.0 & 24.0 & 14.3 \\
\hline 2010 & 8201 & 4431 & 2233 & 7271 & 772.1 & 105 & 4.0 & 3.3 & 4.7 & 0.1 & 1.9 & 175.0 & 88.9 & 302.9 & 32.3 & 18.4 \\
\hline
\end{tabular}

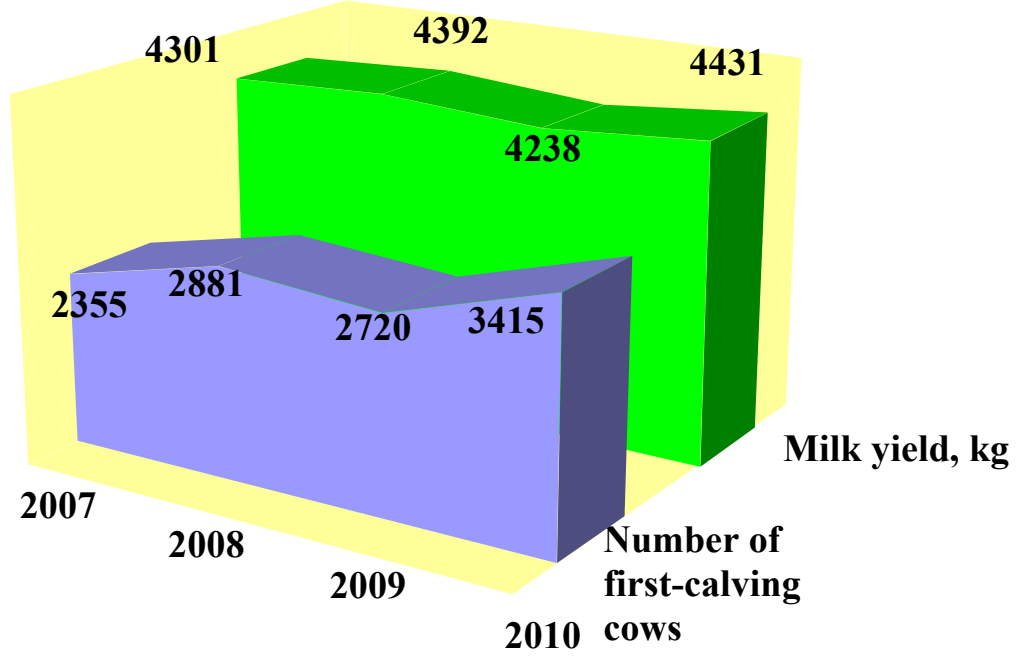

Graph 2. Number and average milk production of first-calving Simmental cows (2007-2010)

Production of milk and milk fat is limited only on one sex, so potential ability of breeding animals for these traits is determined based on production performance of mothers, sisters, daughters, etc. Knowledge of the quality of bull 
sires and how certain traits are passed to progeny is central issue of all breeding programs (Pantelić et al., 2011).

The basis of breeding work is proper selection of animals as parents of future generations of progeny. Genetic progress of herd equally depends on breeding values of male and female breeding animals. Although, at the level of population, a genetic progress of only $15 \%$ is expected through selection of bull dams and cow dams, these two selection directions are exceptionally important for each individual breeder. Milk performance of Simmental first calvers in average was lower by $147 \mathrm{~kg}$ compared to cows in other lactations and by $1.169 \mathrm{~kg}$ compared to milk performance of bull dams in observed period (Graph 2). This difference corresponds to populations with medium genetic potential for milk production (Mcgilliard and Freeman, 1976; Notter et al., 1978) and explains established moderate increase of milk performance in observed period of average $100 \mathrm{~kg}$ per cow annually as reported in the research by Petrović et al (2009).

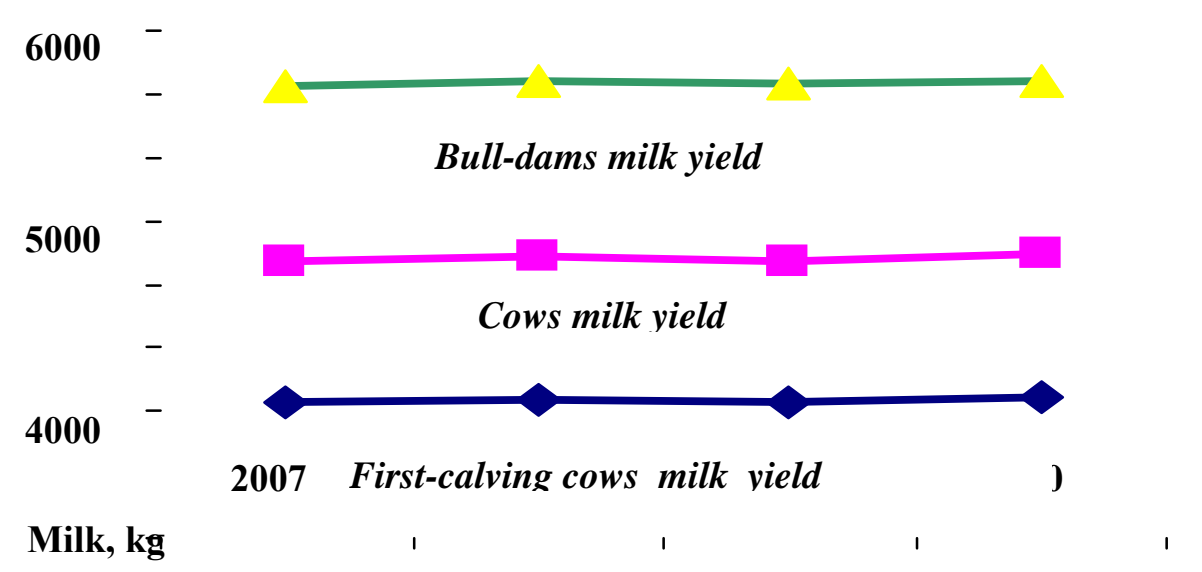

Graph 2. Comparison of milk yield in different categories of Simmental cows

By applying the artificial insemination, the greatest genetic progress of even $85 \%$ in the population of Simmental cattle is achieved through selection of bull and dam sires. In Serbia, insemination is mainly done using the semen from foreign bulls, and less from domestic bulls. First calving cows included in this study ( $\mathrm{N}=11.372)$ were daughters of 124 bulls, and in Table 2 review of ten bulls which were most commonly used in the period 2007 to 2010 and were sires of most of first calving animals in the studied population. It is evident that with the exception of two bulls - Morval and Vostok, other bull sires had negative values 
for milk yield, which consequently can result in poor milk performance results in studied cow generation. Therefore, in next period, it is necessary to carry out strict selection and adequate choice of bulls and cows in Simmental population.

Table 2. Most frequently used bulls-sires of first-calving cows

\begin{tabular}{|c|c|c|c|c|c|}
\hline \multicolumn{2}{|c|}{ Bull-sire } & \multirow{2}{*}{$\begin{array}{c}\text { Number } \\
\text { of } \\
\text { first-calving } \\
\text { daughters }\end{array}$} & \multicolumn{3}{|c|}{ Progeny test results * } \\
\hline $\begin{array}{c}\text { Herd-book } \\
\text { number }\end{array}$ & Name & & $\begin{array}{c}\text { Milk, } \\
\text { kg }\end{array}$ & Milk fat, $\%$ & Milk fat, $\%$ \\
\hline 1440 & Rudolf & 435 & -24.84 & -0.010 & -1.50 \\
\hline 859 & Larsi & 302 & -66.86 & 0.003 & -2.64 \\
\hline 1206 & Morval & 266 & 99.75 & -0.004 & 3.7 \\
\hline 1445 & Zast & 248 & -47.79 & -0.005 & -2.32 \\
\hline 1329 & Motol & 238 & -80.87 & 0.001 & -3.9 \\
\hline 1447 & Sultan & 204 & -15.13 & 0.012 & -0.05 \\
\hline 1394 & Vostok & 192 & 17.37 & -0.062 & -1.91 \\
\hline 1492 & Stier & 189 & -134.64 & -0.003 & -5.16 \\
\hline 1512 & Faktor & 189 & -56.31 & 0.007 & -2.21 \\
\hline 1506 & Ralfurt & 155 & -131.26 & 0.005 & -5.16 \\
\hline
\end{tabular}

*Data of Main Recording Organization (GOO) -Institute for Animal Husbandry

\section{Conclusion}

Number of cattle in Serbia is characterized by decades-long negative trend, and milk production is behind livestock production of developed countries. This is especially unfavourable in the period when bases are acquired for future milk quotas, which are main issue of EU countries. One of the significant pre-conditions for long term ensuring of high-yielding population is systematic work on genetic improvement and rearing of heifers and first-calving cows which represent future generations of dairy herds. Analysis of production characteristics of first-calving cows under control in the period 2007 to 2010 showed that their average milk yield was $4.348 \mathrm{~kg}$ of milk with milk fat content of $3.93 \%$ and milk fat yield of 171.1 $\mathrm{kg}$. With the exception of 2009, milk performance of first calving cows increased continuously in average by approx. $100 \mathrm{~kg}$ per animal and year. Production potential of first-calving cows of Simmental breed in Serbia can be considered satisfactory if economic conditions are taken into consideration which accompany the development of dairy cattle breeding (production structure, excessive import, low purchasing price of raw milk, subsidies, etc.) and reflect on financial independence of breeders and therefore also on poorer conditions for rearing of cows. However, in relation to milk performance of first-calving cows in more advanced Simmental populations (Germany, Austria, Czech Republic), as well as 
set breeding goals in production of milk of over $5.000 \mathrm{~kg}$ of milk with $4,00 \%$ of milk fat in standard lactation, the need for strict selection in population under control becomes apparent. The need for increase of population of cows under control by approx. $20 \%$ is justified, but it has to be accompanied by selection of high quality breeding animals, of known origin and adequate production and reproduction performances. Also, attention must be paid to selection of bull sires, in regard to the results of the progeny testing on milk performance and body development. Results of our research showed that eight of ten bull sires had negative values for milk yield which further indicates the need for better cooperation and organization of all services included in the selection activities in dairy cattle breeding.

Finally, it can be concluded that within the preparations of Serbia for EU accession the decrease of number of animals - cattle population should be compensated by increase of milk yield per cow, which corresponds to global trends in dairy cattle breeding.

\title{
Acknowledgment
}

Research was financed by the Ministry of Education and Science, Republic of Serbia, project TR-31053.

\section{Proizvodni potencijal prvotelki simentalske rase u Srbiji}

\author{
D. Nikšić, D. Ostojić-Andrić, V. Pantelić, P. Perišić, Ž. Novaković, S. Aleksić, M. \\ Lazarević
}

\section{Rezime}

Govedarstvo Srbije a posebno proizvodnja mleka značajno učestvuju u vrednosti ukupne poljoprivredne (20\%) i stočarske proizvodnje (45\%). Postignutim tempom rasta prinosa mleka od oko $100 \mathrm{~kg}$ po kravi godišnje ne može se adekvatno kompenzovati drastičan pad broja mlečnih grla koji je u protekloj deceniji opao za petinu. Ovo je posebno značajno sa aspekta procena budućih proizvodnih kvota za mleko u priprema Srbije za ulazak u EU. Sa aspekta genetskog potencijala mlečnih krava, najznačajnija mera za povećanja prinosa mleka u narednom periodu je sprovođenje sistematskog odgajivačko-selekcijskog rada u matičnoj populaciji. Izboru roditeljskih parova budućih generacija mlečnog stada, kriterijumima odabira junica i njihovom pravilnom odgoju u smislu ishrane i uslova držanja treba posvetiti primaran značaj. U cilju utvrđivanja proizvodnog potencijala prvotelki simentalske rase u Republici Srbiji analizirani su podaci 
37.171 simentalskih krava koje su svoje prve laktacije zaključile u periodu od 2007-2010 godine. Rezultati istraživanja pokazali su umereni trend porasta mlečnosti prvotelki sa ostvarenom prosečnom proizvodnjom od $4.348 \mathrm{~kg}$ mleka, sadržajem od 3,93\% i prinosom od 171,1 kg mlečne masti. Mlečnost prvotelki u proseku je bila niža za $147 \mathrm{~kg}$ od mlečnosti krava u ostalim laktacijama i za 1.169 $\mathrm{kg}$ od mlečnosti bikovskih majki u posmatranom periodu. Analizom bikova najčešćih očeva ispitivanih prvotelki, utvrđeno je da je osam od deset bikova-očeva imalo negativne vrednosti za prinos mleka što upućuje na neophodnost bolje saradnje i organizacije u radu svih službi koje obavljaju odgajivačko-selekcijski rad u mlečnom govedarstvu.

\section{References}

CRV (2010): Coöperatie Rundvee Verbetering. Fleckvieh Annual Report 20092010.

GOO (2010): Glavna odgajivačka organizacija-Institut za stočarstvo: Stručni izveštaj i rezultati obavljenih poslova kontrole mera za sprovođenje odgajivačkog programa u 2010. godini. Beograd-Zemun.

HAWORTH G.M., TRANTER W.P., CHUCK J.N., CHENG Z., WATHES D.C. (2008): Relationships between age at first calving and first lactation milk yield, and lifetime productivity and longevity in dairy cows. Vet Rec., 7, 162, 643-647.

HPA (2010): Hrvatska poljoprivredna agencija, Godišnje izvješće-Govedarstvo. ICAR (2009): International Committee for Animal Recording. Icar guidelines., 1-517. ICAR (2011): International Committee for Animal Recording. Milk recording database, www.icar.org

MCGILLIARD M.L., FREEMAN A.E. (1976): Predicting daughter milk production from dam index. journal of dairy science, 59, 6, 1140-1146.

MEDIĆ D, VESELINOVIĆ S., VESELINOVIĆ S., IVANČEV A., ĆUPIĆ Ž. (2006): Uporedna ispitivanja osobina mlečnosti simentalskih krava domaće i austrijske provincijencije. Simpozijum "Stočarstvo, veterinarstvo i agroekonomija u tranzicionim procesima", Herceg Novi.

MIŠČEVIC B., LAZAREVIĆ R., VIDOVIĆ V., ALEKSIĆ S., PETROVIĆ M.M. (1995): Ocena genetskih varijansi i koeficijenata naslednosti važnijih osobina mlečnosti krava simentalske rase. Biotehnologija u stočarstvu, 11, 3-6, 81-86.

NOTTER D.R., CUNDIFF L.V., SMITH G.M., LASTER D.B., GREGORY K.E. (1978): Effects on preweaning growth of progeny production in young cows and transmitted and maternal characterization of biological types of cattle. VII Milk production in young cows and transmitted and maternal effects on preweaning growth of progeny. J Anim. Sci., 46, 908-921.

PANTELIĆ V., PETROVIĆ M.M, ALEKSIĆ S., SRETENOVIĆ LJ., OSTOJIĆANDRIĆ D., NOVAKOVIĆ Ž. (2008): Investigation of the genetic correlation 
between milk and fertility traits of first calving cows of Simmental breed. Biotechnology in Animal Husbandry, 24, 5-6, 1-8.

PANTELIĆ V., PLAVŠIĆ M., TRIVUNOVIĆ S., ALEKSIĆ S., SRETENOVIĆ LJ., OSTOJIĆ-ANDRIĆ D. NIKŠIĆ D. (2011): The evaluation of breeding value of simmental bulls for milk performance in Serbia. Biotehnology in Animal Husbandry, 27, 2, 127-135.

PERIŠIĆ P., SKALICKI Z., LATINOVIĆ D., PETROVIĆ M.M., RUŽIĆ D. (1999b): Uticaj uzrasta pri prvoj oplodnji na neke reproduktivne i proizvodne osobine prvotelki simentalske rase. Savremena poljoprivreda, 48, 1-2, 155-159.

PETROVIĆ M.M., LAZAREVIĆ LJ., ALEKSIĆ S., MISČEVIĆ B., PERKOVIĆ S., ILIĆ Z. (1999): Comparative investigation of the heritability of milkiness phenotypes in the daughters of Simmental and Holstein-Friesian bull-sires in Serbia. Biotechnology in Animal Husbandry, 15, 5-6, 125-132.

PETROVIĆ M.M., SRETENOVIĆ LJ., PANTELIĆ V., ALEKSIĆ S., MIŠČEVIĆ B., BOGDANOVIĆ V., OSTOJIĆ-ANDRIĆ D., PETROVIĆ M. (2006): Results of the application of the technology of genetic improvement of Simmental cattle population in Serbia. Biotechnology in Animal Husbandry, 22, 1-2, 1-8.

PETROVIĆ M.M., SRETENOVIĆ LJ., BOGDANOVIĆ V., PERIŠIĆ P., ALEKSIĆ S., PANTELIĆ V., PETROVIĆ M.D., NOVAKOVIĆ Ž. (2009): Quantitative analysis of genetic improvement of milk production phenotypes in simmental cows. Biotechnology in Animal Husbandry, 25, 1-2, 45-51.

STATISTICA FOR WINDOWS VERSION 7. StatSoft.Inc (2004), Oxford, UK. STRAPAK P., STRAPAKOVA E. (1997): Milk Production of imported fleckvieh cows. Biotechnology in Animal Husbandry, 13, 5-6, 281-288.

RAJIĆ Z., RALEVIĆ N., LJUBANOVIĆ-RALEVIĆ I., ŽIVKOVIĆ D. (2007): Kapaciteti i proizvodnja mleka u Srbiji. Savremena poljoprivreda, 56, 5 , 1-11. 